DOI: $10.31249 / \mathrm{rsm} / 2018.02 .06$

\title{
Д.О. Вакарчук
}

\section{РОЛЬ СТРАН ЦЕНТРАЛЬНО-ВОСТОЧНОЙ ЕВРОПЫ В ПРОЦЕССЕ СТАНОВАЕНИЯ ВНЕШНЕЙ ЭНЕРГЕТИЧЕСКОЙ ПОАИТИКИ ЕВРОПЕЙСКОГО СОЮЗА (2005-2007)}

Аннотация. В статье рассматривается проблема становления внешней энергетической политики Евросоюза. Расширение ЕC на восток Европь оказало негативное влияние на энергетическую безопасность Союза, а также на его отношения с Россией - главным поставщиком энергоносителей. Украинский энергетический кризис 2006 г. наглядно продемонстрировал возросшую зависимость ЕС от России и активизировал процесс формирования общей внешней энергетической политики Союза. Автор приходит к выводу о том, что конфликт интересов новых и старых членов ЕС в сфере энергетики усложнил процесс становления общей внешней энергетической политики Союза.

Ключевые слова: Европейский союз, страны Центрально-Восточной Европы (ЦВЕ), внешняя энергетическая политика EC, энергетическая безопасность ЕC, энергодиалог Россия - ЕС.

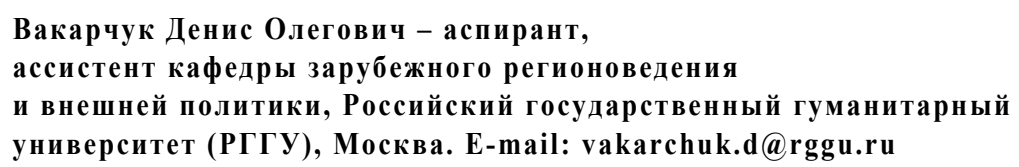

D.O. Vakarchuk. The Role of the Central and Eastern European Countries in the Process of Forming the EU Foreign Energy Policy (2005-2007)

Abstract. The article addresses the issue of forming the external energy policy of the European Union. The eastward enlargement of the EU had a negative impact on the energy security of the Union as well as on the relations of the EU and Russia as the key energy supplier. The 2006 Ukrainian energy crisis clearly demonstrated the increased EU dependence on Russia and intensified the development of the common external energy policy in the EU. However, significant differences in the interests in the energy sector between the CEE new member states and the «old» members of the European Union, in particular regarding the role of the Russian Federation in the energy security of the Union, have complicated the process of forming the common external energy policy of the EU and demonstrated lack of unity within the Union. 
Keywords: European Union, CEE countries, external energy policy of the EU, energy security of the EU, EU-Russia energy dialogue.

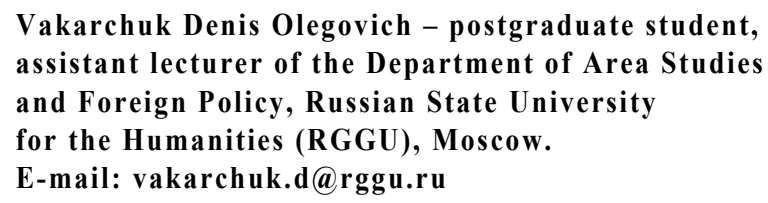

Впервые о необходимости развития общей внешней энергетической политики (ОВЭП) ЕС было сказано в Зеленой книге «Навстречу европейской стратегии безопасности энергообеспечения», разработанной Европейской комиссией (ЕК) в 2000 г. В документе подчеркивалось, что Евросоюз «страдает от отсутствия компетенции и единства по энергетическим проблемам». Более того, в документе говорилось, что «сохранение такой ситуации останется “Ахиллесовой пятой” экономики ЕС, и способность Союза оказывать влияние на энергетические проблемы на глобальном уровне останется ограниченной» [20].

После расширения ЕС в 2004 г. граница союза передвинулась на восток. Польша, Чехия, Словакия, Венгрия, входящие в регион ЦентральноВосточной Европы (ЦВЕ), приобрели статус полноправного члена ЕС. Это сыграло значительную роль в процессе формирования общей энергетической политики Союза, в том числе ее внешнего измерения.

Действительно, новые государства-члены, такие как Польша, Чехия, Словакия и Венгрия, в силу своей географической близости к России в большей степени испытывали зависимость от поставок энергетических ресурсов из последней, чем старые государства-члены. Так, по оценкам ЕК, за счет поставок из России обеспечивалось $60 \%$ потребления газа в Венгрии, 48 в Польше, 98 - в Словакии, 78\% - в Чехии [8]. Для сравнения: старые государства-члены не испытывали подобной зависимости в силу того, что потребление газа этими странами было в большей степени диверсифицировано.

Однако в 2004-2005 гг., несмотря на некоторые разногласия, отношения Евросоюза с Россией развивались в позитивном ключе. В выступлениях европейских политиков постоянно подчеркивалась высокая значимость России как надежного поставщика энергетических ресурсов в государства - члены EC. Кроме того, определенный успех был достигнут в рамках саммитов Россия - ЕС. Так, по итогам 15-го саммита в мае 2005 г. были утверждены дорожные карты четырех общих энергетических пространств [2]. Возражения со стороны политиков стран ЦВЕ вызывал в тот период, главным образом, проект Северо-Европейского газопровода (СЕГ), включенный ЕК в список приоритетных проектов общего интереса (TEN-E) [29]. 


\section{РОССИЯ И МИР В ХХІ ВЕКЕ}

Министр иностранных дел Великобритании Дж. Стро в выступлении перед Европейским парламентом в октябре 2005 г. отметил, что «государства члены ЕС должны диверсифицировать источники энергии и проводить более последовательную политику в отношении нынешних основных поставщиков энергоресурсов. Государства - члены ЕС должны уповать на потенциал общего рынка Союза в отношениях с поставщиками энергоресурсов. Государства-члены должны стремиться к энергоэффективным и чистым технологиям и содействовать развитию действительно открытого энергетического рынка» [16]. Его мысль развил председатель ЕК Ж.-М. Баррозу, который выразил убежденность в том, что «государства - члены ЕС должны работать сообща в энергетической сфере, которая до недавнего времени считалась областью, зарезервированной для государств-членов, посредством установления последовательной энергетической политики» [там же]. В сущности речь шла о необходимости создания общей европейской энергетической политики (ОЕЭП), которая должна была быть представлена ЕК в 2006 г.

Однако газовый конфликт между Россией и Украиной, апогей которого пришелся на начало января 2006 г., внес коррективы в динамику разработки концептуального документа по общей энергетической политике Евросоюза. Следствием данного кризиса стала полуторадневная недопоставка российского газа европейским потребителям. Падение объемов дневных поставок в страны Европейского союза вызвало возмущение по всей Европе. Ко 2 января Венгрия потеряла до 40\% своих российских поставок [27]. В свою очередь Франция, Италия, Австрия, Венгрия, Польша, Чехия и Словакия сообщили о резком падении поставок в объемах от 25 до 40\% [27; 8]. Итогом кризиса стало подписание российско-украинского соглашения о поставках сроком на пять лет [1].

Евросоюз неоднозначно отреагировал на этот кризис. С одной стороны, на совместной пресс-конференции комиссар по энергетике А. Пиебалгс и представитель председательствующей на тот момент в ЕС Австрии М. Бартенштайн отметили, что «Газпром» продолжает оставаться надежным поставщиком газа, однако при этом Европе необходима «политика, направленная на обеспечение безопасности поставок» [23]. С другой стороны, страны ЦВЕ и Балтии выступили с критикой энергетической политики России. Так, 16 января в газете Financial Times было опубликовано письмо, подписанное бывшими премьер-министрами Польши (Е. Бузек), Эстонии (М. Лаар), Латвии (Г. Крастс) и бывшим президентом Литвы (В. Ландсбергис), в котором утверждалось, что «перекрыв кран, "Газпром" показал, как может быть осуществлена угроза прекращения подачи энергоносителя и каково значение слов “энергетическая безопасность” и “диверсификация". Через несколько лет мы будем признательны В. Путину за то, что именно он заставил Европу 
всерьез задуматься об эффективном использовании энергии и большей диверсификации источников» [9].

Таким образом, первый серьезный энергетический кризис обнажил ряд проблем европейской энергетической безопасности, главной из которых стала неравномерная зависимость государств - членов ЕС от внешних поставок энергетических ресурсов. Эту проблему очень точно сформулировал комиссар по энергетике А. Пиебалгс: «...расширение, безусловно, принесло новые вызовы Европейскому союзу. Обеспечение безопасности поставок, безусловно, гораздо более сложная задача для новых государств-членов, чем для старых государств-членов» [14].

Государства - члены ЕС из региона ЦВЕ были услышаны, побудив институты Союза заняться разработкой новой энергетической стратегии, учитывая видение энергетической проблемы государствами ЦВЕ.

Первым практическим шагом в области разработки внешней энергетической политики стали коррективы, которые были внесены в «Европейскую политику соседства» (ЕПС). Так, во время дебатов в ЕП депутат от Великобритании Ч. Теннок в своем докладе относительно перспектив ЕПС отметил, что «энергетическая политика и энергетическая безопасность станут ключевыми элементами ЕПС». Эта инициатива ЕП нашла поддержку у комиссара ЕС по внешним связям и ЕПС Б. Ферреро-Вальднер, которая заявила о намерении «уделить первоочередное внимание разработке эффективной внешней энергетической политики, которая будет нацелена на гарантирование энергоснабжения Евросоюза». В качестве инструментов реализации такой политики были предложены: Договор к Энергетической хартии (ДЭХ), Договор об энергетическом сообществе Юго-Восточной Европы, энергетические диалоги с государствами - участниками ЕПС. Более того, еврокомиссар отметила, что «развитие ЕПС в отношении государств Южного Кавказа остается приоритетным» [17], что также представляло выгоду для ЕС с точки зрения энергетической безопасности.

Вторым шагом стало представление комиссаром А. Пиебалгсом 8 марта 2006 г. стратегического документа ЕС в области энергетики под названием «Европейская стратегия достижения устойчивой, конкурентоспособной и безопасной энергетики», которая тоже получила название «Зеленой книги».

В этом документе ЕК предприняла первую попытку детально определить, что собой представляет ОВЭП ЕС. Ключевыми задачами ОВЭП, по мнению ЕК, должны были стать:

- четкая политика, направленная на обеспечение безопасности и диверсификации энергетических поставок;

- развитие энергетического диалога со странами-производителями, транзитными странами, а также иными международными акторами; 


\section{РОССИЯ И МИР В ХХІ ВЕКЕ}

- создание механизма эффективного реагирования на внешние кризисные ситуации;

- придание проблемам энергетической безопасности международного измерения;

- содействие энергетическому развитию [21].

Таким образом, можно констатировать, что в этом документе были намечены два вектора развития внешней энергетической политики. Во-первых, обеспечение ведущей роли ЕС в борьбе с изменением климата, поскольку «эффективные действия по решению проблемы изменения климата являются неотложными, и ЕС должен продолжать приводить пример и, прежде всего, стремиться к максимально широким международным действиям» [там же]. Во-вторых, гарантирование безопасности поставок в страны - члены Евросоюза. Следовательно, ЕК была сделана попытка учесть интересы как старых стран - членов ЕС, так и новых стран-членов, в частности государств ЦВЕ. По задумке ЕК, успешная реализация данного курса позволила бы ЕС «говорить одним голосом» в международных энергетических отношениях.

Страны ЦВЕ в целом приветствовали предложенную ЕК стратегию. Так, в комментарии о принятии данного документа чешский евродепутат Л. Роучек (PSE) отметил, что «Зеленая книга должна стать отправной точкой для начала обсуждения, результатом которого станет подлинная ОВЭП Европы» [11].

Тем не менее с критикой в отношении Зеленой книги выступил ЕП, в резолюции которого констатировался факт отсутствия новых целей, конкретных предложений и разработанного плана действий [19].

Проблема энергетической безопасности стала одним из центральных пунктов повестки дня весеннего саммита ЕС 23-24 марта 2006 г., на котором были подведены предварительные итоги в деле формирования ОЕЭП союза. Относительно ее внешнего измерения главы государств и правительств государств - членов ЕС поручили ЕК и Высокому представителю Союза по внешней политике подготовить доклад о перспективе внешних энергетических отношений Союза.

Итогом совместной работы двух институтов стал доклад «Внешняя политика на службе энергетических интересов Европы» [7]. По мнению отечественных исследователей С.В. Седых и Б.Е. Зарицкого, «сам факт такой совместной инициативы свидетельствовал о том, что речь идет о попытке инкорпорировать энергетическую политику во внешнюю политику Евросоюза» [6, с. 84]. Этот документ важен по нескольким причинам. Во-первых, по мнению авторов, «повышенная зависимость от импорта из нестабильных регионов и поставщиков представляет серьезный риск для ЕС» [там же]. Во-вторых, в тексте документа было зафиксировано, что «некоторые крупные производители и потребители используют энергию как политический 
рычаг» [7]. Таким образом, опосредованно выражалась озабоченность политизацией энергетической сферы со стороны РФ. Механизм решения этих проблем, по мнению европейских политиков, заключался в «развитии согласованной и сосредоточенной внешней энергетической политики ЕС, основанной на полном объеме внутренней и внешней политики ЕС, которая укрепит внешнюю энергетическую безопасность Союза в целом» [там же]. Таким образом, в документе оправдывалась необходимость оформления внешней энергетической политики Союза.

В итоге доклад «Внешняя политика на службе энергетических интересов Европы» был вынесен на рассмотрение глав государств на летнем саммите ЕС в 2006 г. В заключительном документе саммита главы государств признали важность развития внешней энергетической политики Союза и, следовательно, необходимость ее включения в план действий по общей энергетической политике, который должен был быть принят на весеннем саммите ЕС в 2007 г. Кроме того, Европейский совет рекомендовал институтам Союза, отвечающим за внешние отношения, сосредоточиться на осуществлении ряда действий в области внешней энергетической политики. Приоритет отдавался трем ключевым мерам: во-первых, завершению переговоров по Транзитному протоколу и обеспечению ратификации ДЭХ всеми участниками соглашения; во-вторых, интегрированию энергетического раздела в новое соглашение о партнерстве и сотрудничестве с Россией; в-третьих, расширению внутреннего энергетического рынка ЕС на пограничные с Союзом страны [25].

Тем не менее процесс формирования ОВЭП осложнялся в связи с неопределенностью в отношениях между Евросоюзом и Российской Федерацией.

По мнению профессора А.С. Маас, источниками напряженности между ЕС и РФ в рассматриваемый период выступили три фактора: внутренняя фрагментация ЕС - в частности трения между «старыми» и «новыми» государствами-членами, между Советом, Европейским парламентом и Европейской комиссией относительно внешнеполитического курса применительно к России; двустороннее ухудшение отношений между Россией и странами ЦВЕ; растущее расхождение между ценностями и целями, которые руководство Союза пыталось продвигать в отношениях с Москвой и растущей самостоятельностью последней во внешне- и внутриполитических ориентиpax [22, p. 113-114].

Несмотря на осторожный оптимизм, высказываемый европейскими политиками, Россия не изменила своего негативного отношения к ратификации ДЭХ. Так, на пресс-конференции по итогам саммита Россия - ЕС в Сочи 25 мая 2006 г. Президент России В.В. Путин заявил: «Если наши партнеры ждут от нас какого-то эксклюзива, ждут, что мы выстроим абсолютно либеральную политику в доступе к инфраструктуре, добыче и транспортировке, то у нас возникает вопрос: что мы получаем взамен? Может, тоже доступ 
к инфраструктуре, добыче и транспорту, но какой, где у вас добыча, в какие вы нас пустите месторождения, какие у вас есть магистральные трубопроводы? Если этого нет - а этого нет, - тогда мы должны найти способ адекватного возмещения или встречного движения в интересах друг друга» [4].

Еще один источник напряжения - двустороннее ухудшение отношений между Россией и странами ЦВЕ - оказал непосредственное влияние на формирование ОВЭП ЕС. Действительно, перманентные кризисные ситуации между странами ЦВЕ и Россией в сфере энергетики в рассматриваемый период вынуждали европейские институты уделять особое внимание обеспечению безопасности поставок при формировании ключевых целей энергетической политики Союза. К таким событиям можно отнести аварию на нефтепроводе «Дружба» в июле 2006 г., продолжение строительства СЕГ, энергетический кризис между Россией и Белоруссией в январе 2007 г.

Надежда на разрешение этих кризисных ситуаций при помощи вмешательства механизмов ЕС побуждала политиков из стран ЦВЕ активно критиковать Россию в рамках дискуссий во всех институтах Союза. Безусловно главным источником напряжения в отношениях между странами ЦВЕ и Россией продолжал оставаться СЕГ. Так, министр обороны Польши Р. Сикорский «сравнил германо-российскую газопроводную сделку с пактом Молотова Риббентропа 1939 г.». Более того, по словам министра обороны Польши, «Польша просила канцлера Германии А. Меркель отказаться от сделки, о которой договорился ее предшественник Г. Шрёдер. Но Германия отвергла эту инициативу» [24].

Руководство Союза не спешило занимать солидарную со странами ЦВЕ позицию в отношении России. На этот факт указал А. Пиебалгс в своем выступлении перед ЕП: «Сегодня Россия играет важнейшую роль в обеспечении поставок энергии в Европу. В настоящее время Россия обеспечивает почти $30 \%$ импорта нефти ЕС и $45 \%$ импорта газа. Или, если быть точнее, $25 \%$ нашего потребляемого газа. В результате Россия является крупнейшим поставщиком внешних энергоносителей... Принимая во внимание ожидаемый рост потребления энергии в ЕС, я считаю, что Россия продолжит поставлять около $25 \%$ потребляемого в ЕС газа, что в абсолютном выражении означает увеличение поставок» [13].

Если рассматривать фактор внутренней фрагментации ЕC, а именно противоречия между основными институтами Союза, то наиболее показательным примером в рассматриваемый исторический отрезок стал неформальный саммит Россия - ЕС в Лахти от 20 октября 2006 г. Саммит состоялся в период председательства Финляндии в Совете; эта страна провозгласила внешнее измерение энергетических отношений одним из ключевых аспектов своей программы. Следует отметить, что у руководства ЕС не было согласованной позиции в отношении России на саммите. Накануне его проведения в рамках 
ЕП разгорелись дискуссии относительно позиции, которую должны выбрать главы государств и правительств ЕС в рамках диалога с Россией. Следует отметить, что как представители новых государств-членов, так и представители старых государств - членов ЕС заняли в большинстве своем критическую позицию в отношении Москвы и призвали руководство ЕС включить в повестку дня не только энергетическую проблему, но и вопрос несоблюдения демократических прав в России. Наиболее яркими сторонниками такого подхода выступили британские и польские евродепутаты. Так, Г. Уотсон, лидер Европейского союза либералов и демократов, призвал государства члены ЕС «поддерживать твердую линию в отношении России, осуждая нападения на демократические права и свободы». В свою очередь, польский политик Б. Клих (PPE-DE) заявил, что «только уважение прав человека и гражданских свобод в России может стать условием дальнейшего политического диалога с этой страной» [15].

Обсуждение проблемы сотрудничества ЕС и России в области энергетики происходило, но ощутимого прогресса в переговорах достигнуть не удалось - во многом потому, что лидеры ЕС не смогли договориться между собой о путях «воздействия» на Россию. Так, перед саммитом лидер Германии А. Меркель напутствовала коллег «на ориентацию России к более конструктивным позициям по повестке дня» [28]. В свою очередь, конфронтационную позицию в отношении России приняли президент Польши и премьерминистры Швеции, Дании и Латвии. Таким образом, очередные попытки европейских политиков побудить Россию к ратификации ДЭХ и либерализации энергетического рынка закончились безрезультатно, обнажив проблему единства институтов ЕС в деле достижения общих целей Союза.

Между тем на брифинге после саммита В.В. Путин заявил: «Мы не против принципов, изложенных в Энергетической хартии, но мы считаем, что некоторые положения необходимо уточнить». Кроме того, он выразил уверенность, что «ЕС и Россия будут в состоянии разработать общие подходы к энергетическому сотрудничеству, которые будут включены в “новый документ”» [18]. Тем не менее саммит в Лахти стал первой попыткой Союза проводить единую внешнюю политику в энергетической сфере.

В январе 2007 г. ЕК, главный проводник общей энергетической политики $\mathrm{EC}$, представила новый установочный документ - «Энергетическая политика для Европы» [10], в котором были окончательно сформулированы приоритеты и меры внешней общей энергетической политики Союза. По мнению российского исследователя И.Г. Пашковской, именно в этом документе «энергетическая политика Союза впервые была названа “международной энергетической политикой”» [3, с. 61]. Главный акцент в документе был сделан «на активизацию Союзом международных усилий по борьбе с климатическими изменениями», а не на активную внешнюю энергетическую политику 
Союза в отношении России, как того желали страны ЦВЕ [10]. Критику такого подхода ЕК выразила представитель Чехии в ЕП Я. Бобошикова, которая в своей речи заявила: «Я очень разочарована тем, что отправной точкой переговоров по энергетике в рамках Европейского совета является борьба с изменением климата. Президиум должен подготовить правильное предложение о том, как гарантировать бесперебойные поставки из России во все ЕC, а не только в Германию» [12].

Критика этого документа политиками из стран ЦВЕ привела к тому, что в Плане действий на 2007-2009 гг. «Энергетическая политика для Европы» на первое место в международной энергетической политике ЕС была выдвинута проблемы безопасности поставок [26]. Внешняя климатическая политика Союза, в свою очередь, «была выведена за пределы Плана действий и включена в Лиссабонскую стратегию» [5, с. 252]. В результате положения данного документа нашли поддержку со стороны политиков из стран ЦВЕ.

Таким образом, можно сделать вывод, что в процессе формирования ОВЭП руководство Европейского союза столкнулось с объективными сложностями, причина которых - в различиях между государствами - членами ЕС в ви́дении приоритетов такой политики. Серьезная зависимость стран ЦВЕ от внешних энергетических поставок, преимущественно поставок из России, стала причиной перманентного лоббирования этими странами политики, основанной на идее важности обеспечения безопасности поставок и реализации принципа европейской солидарности в энергетических переговорах с Россией. Реальным результатом такой политики, стала корректировка приоритетов энергетической политики институтами Союза на концептуальном уровне, от климатической дипломатии к обеспечению безопасности поставок. Тем не менее на практике различия между старыми и новыми странами - членами ЕС в ви́дении приоритетов внешней энергетической политики не исчезли.

\section{Библиография}

1. Газпром: Конфликт между Россией и Украиной урегулирован // Коммерсантъ. ru. 2006. 4 января. URL: https://www.kommersant.ru/doc/988518?query=украина\%20газ (Дата обращения: 16.08.2016.)

2. На саммите Россия - Европейский союз утверждены «дорожные карты» четырех общих пространств // Президент России: Официальный сайт. 2005. 10 мая. URL: http://kremlin.ru/ events/president/news/33337 (Дата обращения: 18.08.2016.)

3. Пашковская И.Г. Внешняя энергетическая политика Европейского союза // Мировая экономика и международные отношения. 2009. № 1. С. 61-69.

4. Пресс-конференция В.В. Путина по итогам саммита Россия - ЕС // Президент России: Официальный сайт. 2006. 25 мая. URL: http://kremlin.ru/events/president/transcripts/23595 (Дата обращения: 16.08.2016.) 
5. Сафонова Ю.А. Роль «Новой» Европы в формировании новой энергетической политики Европейского союза (2007-2009 гг.). Дис. на... канд. ист. наук: 07.00.03. М.: МГУ, 2013. $385 \mathrm{c}$.

6. Седых С.В., Зарицкий Б.Е. Энергетическая политика ФРГ. М.: Магистр; ИНФРА-М, 2016. $176 \mathrm{c}$.

7. An External Policy to Serve Europe's Energy Interests: Paper from Commission for the European Council // European Council: Official Website. URL: http://www.consilium.europa.eu/ ueDocs/cms_Data/docs/pressData/en/reports/90082.pdf (Дата обращения: 10.09.2016.)

8. Assessment report of directive 2004/67/EC on security of gas supply. Brussels: Commission of the European Communities, 2009. 76 p. URL: http://eur-lex.europa.eu/LexUriServ/LexUriServ. do?uri=SEC:2009:0978:FIN:EN:PDF (Дата обращения: 18.06.2017.)

9. Baltic politicians assail Russia for energy policy // The Baltic Times. 2006. Jan. 18. URL: https://www.baltictimes.com/news/articles/14425/ (Дата обращения: 21.09.2017.)

10. Communication from the Commission to the European Council and the European Parliament. An Energy policy for Europe. Brussels: Commission of the European Communities, 2007. 27 p. URL: http://www.europarl.europa.eu/meetdocs/2004_2009/documents/com/com_com(2007)0001_/ com_com(2007)0001_en.pdf (Дата обращения: 18.06.2017.)

11. Debates. Monday, 13 March 2006. Strasbourg // European Parliament: Official Website. URL: http://www.europarl.europa.eu/sides/getDoc.do?pubRef=\%2f\%2fEP\%2f\%2fTEXT\%2bCRE\% 2b20060313\%2bITEM-016\%2bDOC\%2bXML\%2bV0\%2f\%2fEN\&language=EN (Дата обращения: 01.08.2016.)

12. Debates. Tuesday, 13 February 2007. Strasbourg // European Parliament: Official Website. URL: http://www.europarl.europa.eu/sides/getDoc.do?pubRef=\%2f $\% 2 \mathrm{fEP} \% 2 \mathrm{f} \% 2 \mathrm{fTEXT} \% 2 \mathrm{bCRE} \%$ 2b20070213\%2bITEM-008\%2bDOC\%2bXML\%2bV0\%2f\%2fEN\&language=EN (Дата обращения: 10.08.2016.)

13. Debates. Tuesday, 16 May 2006. Strasbourg // European Parliament: Official Website. URL: http://www.europarl.europa.eu/sides/getDoc.do?pubRef=\%2f\%2fEP\%2f\%2fTEXT\%2bCRE\% 2b20060516\%2bITEM-015\%2bDOC\%2bXML\%2bV0\%2f\%2fEN\&language=EN (Дата обращения: 01.08.2016.)

14. Debates. Tuesday, 17 January 2006. Strasbourg // European Parliament: Official Website. URL: http://www.europarl.europa.eu/sides/getDoc.do?pubRef=\%2f $\% 2 \mathrm{fEP} \% 2 \mathrm{f} \% 2 \mathrm{fTEXT} \% 2 \mathrm{bCRE} \%$ 2b20060117\%2bITEM-011\%2bDOC\%2bXML\%2bV0\%2f\%2fEN\&language=EN (Дата обращения: 10.09.2016.)

15. Debates. Wednesday, 11 October 2006. Strasbourg // European Parliament: Official Website. URL: http://www.europarl.europa.eu/sides/getDoc.do?pubRef=\%2f\%2fEP\%2f\%2fTEXT\% 2bCRE\%2b20061011\%2bITEM-014\%2bDOC\%2bXML\%2bV0\%2f\%2fEN\&language $=\mathrm{EN} \quad$ (Дата обращения: 10.08.2016.)

16. Debates. Wednesday, 16 November 2005. Strasbourg // European Parliament: Official Website. URL: http://www.europarl.europa.eu/sides/getDoc.do?pubRef=\% $\% 2 \mathrm{f} \% 2 \mathrm{fEP} \% 2 \mathrm{f} \% 2 \mathrm{fTEXT} \%$ 2bCRE\%2b20051116\%2bITEM-016\%2bDOC\%2bXML\%2bV0\%2f\%2fEN\&language $=E N \quad$ (Дата обращения: 10.08.2016.)

17. Debates. Wednesday, 18 January 2006. Strasbourg // European Parliament: Official Website. URL: http://www.europarl.europa.eu/sides/getDoc.do?pubRef $=\% 2 \mathrm{f} \% 2 \mathrm{fEP} \% 2 \mathrm{f} \% 2 \mathrm{fTEXT} \% 2 \mathrm{~b}$ CRE\%2b20060118\%2bITEM-012\%2bDOC\%2bXML\%2bV0\%2f\%2fEN\&language=EN (Дата обращения: 01.08.2016.)

18. EU, Russia make slow progress on energy // Euractiv. 2006. Oct. 23. URL: https://www. euractiv.com/section/med-south/news/eu-russia-make-slow-progress-on-energy/ (Дата обращения: 10.09.2016.) 


\section{РОССИЯ И МИР В ХХІ ВЕКЕ}

19. European Parliament resolution on security of energy supply in the European Union. 23 March 2006 // European Parliament: Official Website. URL: http://www.europarl.europa. eu/sides/getDoc.do?objRefId=112190\&language=EN (Дата обращения: 10.09.2016.)

20. Green Paper - Towards a European strategy for the security of energy supply: Communication from the Commission to the European Parliament and the Council // EUR-Lex Access to European Union law. URL: http://eur-lex.europa.eu/legal-content/EN/TXT/HTML/?uri=CELEX: 52000DC0769\&from=en (Дата обращения: 18.06.2017.)

21. Green paper. A European Strategy for Sustainable, Competitive and Secure Energy. Brussels: Commission of the European Communities, 2006. 20 p. URL: http://europa.eu/documents/ comm/green_papers/pdf/com2006_105_en.pdf (Дата обращения: 22.10.2017.)

22. Maass A-S. EU-Russia Relations, 1999-2015. From Courtship to Confrontation. N.Y.: Routledge, 2017. 204 p.

23. Piebalgs A. Speaking Notes welcoming the agreement between Gazprom and Naftogaz // European Commission press release database. URL: http://europa.eu/rapid/press-release_SPEECH06-1_en.htm (Дата обращения: 20.09.2017.)

24. Polish DM Likens Pipeline Deal To Nazi-Soviet Pact // RadioFreeEurope. 2006. Apr. 30. URL: https://www.rferl.org/a/1068062.html (Дата обращения: 10.09.2016.)

25. Presidency Conclusions of the Brussels European Council 15/16 June 2006. Brussels: Commission of the European Communities, 2006. 37 p. URL: http://www.consilium.europa.eu/ ueDocs/cms_Data/docs/pressData/en/ec/90111.pdf (Дата обращения: 03.11.2017.)

26. Presidency Conclusions of the Brussels European Council 8/9 March 2007. Brussels: Commission of the European Communities, 2007. 37 p. URL: http://www.consilium.europa.eu/ uedocs/cms_data/docs/pressdata/en/ec/93135.pdf (Дата обращения: 03.11.2017.)

27. Russia vows to end gas shortage // BBC News Website. 2006. Jan. 2. URL: http://news. bbc.co.uk/2/hi/europe/4575726.stm (Дата обращения: 05.11.2017.)

28. Spongeberg H. Secret minutes of EU-Russia meeting found in bin // EU Observer. 2006. Nov. 13. URL: https://euobserver.com/foreign/22842 (Дата обращения: 05.11.2017.)

29. Trans-European energy networks: TEN-E priority projects. Luxembourg: Office for Official Publications of the European Communities, 2004. 44 p. URL: http:/ec.europa.eu/ten/energy/studies/ doc/2004_brochure/ten_e_priority_projects_2004_en.pdf (Дата обращения: 01.08.2016.)

\section{References}

An External Policy to Serve Europe's Energy Interests: Paper from Commission for the European Council // European Council: Official Website. URL: http://www.consilium.europa.eu/ueDocs/ cms_Data/docs/pressData/en/reports/90082.pdf (Data obrashhenija: 10.09.2016.)

Assessment report of directive 2004/67/EC on security of gas supply. Brussels: Commission of the European Communities, 2009. 76 p. URL: http://eur-lex.europa.eu/LexUriServ/LexUriServ. do?uri=SEC:2009:0978:FIN:EN:PDF (Data obrashhenija: 18.06.2017.)

Baltic politicians assail Russia for energy policy // The Baltic Times. 2006. Jan. 18. URL: https://www.baltictimes.com/news/articles/14425/ (Data obrashhenija: 21.09.2017.)

Communication from the Commission to the European Council and the European Parliament. An Energy policy for Europe. Brussels: Commission of the European Communities, 2007. 27 p. URL: http://www.europarl.europa.eu/meetdocs/2004_2009/documents/com/com_com(2007)0001_/com_co m(2007)0001_en.pdf (Data obrashhenija: 18.06.2017.)

Debates. Monday, 13 March 2006. Strasbourg // European Parliament: Official Website. URL: http://www.europarl.europa.eu/sides/getDoc.do?pubRef=\%2f\%2fEP\%2f\%2fTEXT\%2bCRE\%2b2006 
0313\%2bITEM-016\%2bDOC\%2bXML\%2bV0\%2f\%2fEN\&language=EN (Data obrashhenija: 01.08.2016.)

Debates. Tuesday, 13 February 2007. Strasbourg // European Parliament: Official Website. URL: http://www.europarl.europa.eu/sides/getDoc.do?pubRef $=\% 2 \mathrm{f} \% 2 \mathrm{fEP} \% 2 \mathrm{f} \% 2 \mathrm{fTEXT} \% 2 \mathrm{bCRE} \%$ 2b20070213\%2bITEM-008\%2bDOC\%2bXML\%2bV0\%2f\%2fEN\&language=EN (Data obrashhenija: 10.08.2016.)

Debates. Tuesday, 16 May 2006. Strasbourg // European Parliament: Official Website. URL: http://www.europarl.europa.eu/sides/getDoc.do?pubRef $=\% 2 \mathrm{f} \% 2 \mathrm{fEP} \% 2 \mathrm{f} \% 2 \mathrm{fTEXT} \% 2 \mathrm{bCRE} \% 2 \mathrm{~b} 2006$ 0516\%2bITEM-015\%2bDOC\%2bXML\%2bV0\%2f\%2fEN\&language $=\mathrm{EN} \quad$ (Data obrashhenija: 01.08.2016.)

Debates. Tuesday, 17 January 2006. Strasbourg // European Parliament: Official Website. URL: http://www.europarl.europa.eu/sides/getDoc.do?pubRef=\%2f\%2fEP\%2f\%2fTEXT\%2bCRE\%2b2006 0117\%2bITEM-011\%2bDOC\%2bXML\%2bV0\%2f\%2fEN\&language=EN (Data obrashhenija: 10.09.2016.)

Debates. Wednesday, 11 October 2006. Strasbourg // European Parliament: Official Website. URL: http://www.europarl.europa.eu/sides/getDoc.do?pubRef $=\% 2 \mathrm{f} \% 2 \mathrm{fEP} \% 2 \mathrm{f} \% 2 \mathrm{fTEXT} \% 2 \mathrm{bCRE} \%$ 2b20061011\%2bITEM-014\%2bDOC\%2bXML\%2bV0\%2f\%2fEN\&language=EN (Data obrashhenija: 10.08.2016.)

Debates. Wednesday, 16 November 2005. Strasbourg // European Parliament: Official Website. URL: http://www.europarl.europa.eu/sides/getDoc.do?pubRef $=\% 2 \mathrm{f} \% 2 \mathrm{fEP} \% 2 \mathrm{f} \% 2 \mathrm{fTEXT} \% 2 \mathrm{bCRE} \%$ 2b20051116\%2bITEM-016\%2bDOC\%2bXML\%2bV0\%2f\%2fEN\&language=EN (Data obrashhenija: 10.08.2016.)

Debates. Wednesday, 18 January 2006. Strasbourg // European Parliament: Official Website. URL: http://www.europarl.europa.eu/sides/getDoc.do?pubRef $=\% 2 \mathrm{f} \% 2 \mathrm{fEP} \% 2 \mathrm{f} \% 2 \mathrm{fTEXT} \% 2 \mathrm{bCRE} \%$ 2b20060118\%2bITEM-012\%2bDOC\%2bXML\%2bV0\%2f\%2fEN\&language=EN (Data obrashhenija: 01.08.2016.)

EU, Russia make slow progress on energy // Euractiv. 2006. Oct. 23. URL: https://www. euractiv.com/section/med-south/news/eu-russia-make-slow-progress-on-energy/ (Data obrashhenija: 10.09.2016.)

European Parliament resolution on security of energy supply in the European Union. 23 March 2006 // European Parliament: Official Website. URL: http://www.europarl.europa.eu/sides/getDoc. do? objRefId=112190\&language=EN (Data obrashhenija: 10.09.2016.)

Gazprom: Konflikt mezhdu Rossiej i Ukrainoj uregulirovan // Kommersant.ru. 2006. Jan. 4. URL: https://shhshhshh.kommersant.ru/doc/988518?jauery=ukraina\%20gaz (Data obrashhenija: 16.08.2016.)

Green Paper - Towards a European strategy for the security of energy supply: Communication from the Commission to the European Parliament and the Council // EUR-Lex Access to European Union law. URL: http://eur-lex.europa.eu/legal-content/EN/TXT/HTML/?uri=CELEX:52000DC 0769\& from=en (Data obrashhenija: 18.06.2017.)

Green paper. A European Strategy for Sustainable, Competitive and Secure Energy. Brussels: Commission of the European Communities, 2006. 20 p. URL: http:/europa.eu/documents/ comm/green_papers/pdf/com2006_105_en.pdf(Data obrashhenija: 22.10.2017.)

Maass A-S. EU - Russia Relations, 1999-2015. From Courtship to Confrontation. N.Y.: Routledge, 2017. 204 p.

$\mathrm{Na}$ sammite Rossija-Evropejskij sojuz utverzhdeny «dorozhnye karty» chetyreh obshhih prostranstv // Prezident Rossii: Oficial'nyj sajt. 2005. 10 maja. URL: http://kremlin.ru/events/ president/neshhs/33337 (Data obrashhenija: 18.08.2016.) 


\section{РОССИЯ И МИР В ХХІ ВЕКЕ}

Pashkovskaja I.G. Vneshnjaja jenergeticheskaja politika Evropejskogo sojuza // Mirovaja jekonomika i mezhdunarodnye otnoshenija. 2009. N 1. C. 61-69.

Piebalgs A. Speaking Notes welcoming the agreement between Gazprom and Naftogaz // European Commission press release database. URL: http://europa.eu/rapid/press-release_SPEECH06-1_en.htm (Data obrashhenija: 20.09.2017.)

Polish DM Likens Pipeline Deal To Nazi-Soviet Pact // RadioFreeEurope. 2006. Apr. 30. URL: https://www.rferl.org/a/1068062.html (Data obrashhenija: 10.09.2016.)

Presidency Conclusions of the Brussels European Council 15/16 June 2006. Brussels: Commission of the European Communities, 2006. 37 p. URL: http://www.consilium.europa. eu/ueDocs/cms Data/docs/pressData/en/ec/90111.pdf (Data obrashhenija: 03.11.2017.)

Presidency Conclusions of the Brussels European Council 8/9 March 2007. Brussels: Commission of the European Communities, 2007. 37 p. URL: http://www.consilium.europa.eu/ uedocs/cms_data/docs/pressdata/en/ec/93135.pdf (Data obrashhenija: 03.11.2017.)

Press-konferencija V.V. Putina po itogam sammita Rossija - ES // Prezident Rossii: Oficial'nyj sajt. 2006. May 25. URL: http://kremlin.ru/events/president/transcripts/23595 (Data obrashhenija: 16.08.2016.)

Russia vows to end gas shortage // BBC News Website. 2006. Jan. 2. URL: http://news.bbc. co.uk/2/hi/europe/4575726.stm (Data obrashhenija: 05.11.2017.)

Safonova Ju.A. Rol' «Novoj» Evropy v formirovanii novoj jenergeticheskoj politiki Evropejskogo Sojuza (2007-2009 gg.). Dis. na... kand. ist. nauk: 07.00.03. M.: MGU, 2013. 385 p.

Sedyh S.V., Zarickij B.E. Jenergeticheskaja politika FRG. M.: Magistr; INFRA-M, 2016. 176 p.

Spongeberg H. Secret minutes of EU - Russia meeting found in bin // EU Observer. 2006. Nov. 13. URL: https://euobserver.com/foreign/22842 (Data obrashhenija: 05.11.2017.)

Trans-European energy networks: TEN-E priority projects. Luxembourg: Office for Official Publications of the European Communities, 2004. 44 p. URL: http://ec.europa.eu/ten/energy/studies/ doc/2004_brochure/ten_e_priority_projects_2004_en.pdf (Data obrashhenija: 01.08.2016.) 